\title{
BIODIVERSITY AND ENZYME ACTIVITY OF INDIGENOUS CELLULOLYTIC AND AMYLOLYTIC BACTERIAS IN DECAYED MANGROVE STEM WASTE PRODUCT AT WAAI SEASHORE, AMBON ISLAND
}

\author{
Utami Sri Hastuti ${ }^{1}$, Kristin Sangur ${ }^{2}$, Henny Nurul Khasanah ${ }^{3}$ \\ Biology Departement FMIPA - State University of Malang, Malang - Indonesia \\ email: tuti_bio_um@yahoo.com \\ Educational Biology - Post Graduate - State University of Malang, Malang - Indonesia \\ email: sangur_kristin@yahoo.com \\ Biology Departement FMIPA - State University of Malang, Malang - Indonesia \\ email: khasanah_henny@yahoo.com
}

\begin{abstract}
Mangrove (Sonneratia spp.) could be found at Waai seashore, Ambon Island. The remainder of the mangrove stem will be decayed and become the waste product. Some indigenous bacteria species that live in the decayed mangrove stem waste product have cellulolytic and amylolytic characters. The objectives of this research were to: 1 ) identify and determine the cellulolytic bacteria species; 2 ) identify and determine the amylolytic bacteria spesies; 3 ) determine the cellulolytic bacteria species that have the highest cellulase activity; 4) determine the amylolytic bacteria species that have the highest amylase activity. This research was conduct at the Microbiology Laboratory-Biology Departement-State University of Malang, Microbiology Laboratory-Faculty of Medicine-Brawijaya University, Chemistry Laboratory-Muhammadiyah Malang University. Twenty five grams sample were ground and diluted in $225 \mathrm{ml}$ nutrient broth to get $10^{-1}$ suspension. Then the suspension were diluted gradually until $10^{-10}$. The suspension were inoculated on nutrient agar medium 0.1 $\mathrm{ml}$ each, and incubated in $37^{\circ} \mathrm{C}$ during $1 \times 24$ hours. Each bacteria colonies were isolated and determine to know which one were the cellulolytic and the amylolytic bacteria. The bacteria isolates were identify. Afterward the cellulase activity as well as the amylase activity were analyzed. The research results shows that: 1) there are 4 cellulolytic bacteria spesies, i.e: Micrococcus luteus, Bacillus pumilus, Planococcus citreus, and Bacillus cereus; 2) there are 4 amylolytic bacteria species, i.e: Bacillus firmus, Nitrobacter sp., Bacillus mycoides, and Pseudomonas aeruginosa; 3) Bacillus cereus has the highest cellulase activity; 4) Nitrobacter $s p$. has the highest amylase activity.
\end{abstract}

Keywords: biodiversity, cellulolytic bacteria, amylolytic bacteria, decayed mangrove stem waste product.

\section{INTRODUCTION}

Mangroves have a function as the habitat for the sea animals i.e.: crab, fish, shrimp, mollusc, etc. The mangrove wood have a social economically value, i.e.: for building, meubelair, and handycraft. Mangrove also have another function, i.e.: to protect the sea shore from the abration, place for nursery, take the food and for spawning of some sea biota (Setyawan, et al., 2003). Commonly the people who live at the Waai sea shore, Ambon Island, Moluccas often neglect the role of mangroves in the ecosystem. They cut the mangrove and use as a burned wood. The remainder of the cutted mangrove stem will be decayed for a long time and become a waste product at Waai sea shore. The decayed mangrove stem will become the waste product contains carbohydrate compunds, : cellulose and amylum as same as the waste product from the agriculture industry, i.e.: corn peel, sago pith, and coffee skin. Some indigenous cellulolytic bacteria species live in the decayed mangrove stem waste product and could degrade the cellulose to be more simple compound. The cellulolytic bacteria can be used to degrade the waste product that contains cellulose. Besides that there are also 
live some indigenous amylolytic bacteria species and could degrade the amylum compound to be more simple compound, so it could solute easily. Based on this fact, it is important to isolate and identify the indigenous cellulolytic and amylolytic bacteria in decayed mangrove stem in order to use the bacteria for biodegradation process.

The research result of Apun, et. al., (2000) proved that in the sago pith waste product from Pusa Sarawak, Malaysia founded an indigenous amylolytic and cellulolytic bacteria, i.e.: Bacillus amyloliquefaciens (Apun et al., 2000). The research result of Hastuti et.al. (2013) have also reported that in the sago waste product from Susupu, North Moluccas lived some indigenous amylolytic as well as cellulolytic bacteria species, i.e: Serratia liquefaciens, Bacillus licheniformis, and Bacillus cereus. According to Chou et.al.(2012) based on their research, there are cellulolytic bacteria: Acinetobacter iwofii and Bacillus licheniformis in the some herbivore feces, i.e: zebra, camel, giraffe, and sheep.

Mangrove at Waai sea shore, Ambon island were dominated by genera Sonneratia, because the substrat and the environtment condition were match as the habitat of this genera (Lekatompessy, 2010). The environtment of Waai sea shore were match as the habitat of indigenous cellulolytic and amylolytic bacteria in the decayed mangrove stem (Sonneratia spp.) that contains cellulose and amylum. Cellulolytic bacteria is a group of bacteria that have cellulase enzyme, this enzyme play a role in the degradation process of cellulose, to become the glucose. The cellulose degradation ability could be different between each cellulolytic bacteria. Each cellulolytic bacteria produce different cellulose enzim complex, based on their gen and Carbon source that they use (Meryandini et al., 2009). Each amylolytic bacteria ability to amylum degradation could be different between each other, so it is important to analyze the celluloce and amylum degradation ability of the cellulolytic and amylolytic bacteria isolated from decayed mangrove stem. This research is done to: 1) identify and determine the cellulolytic bacteria species; 2) identify and determine the amylolytic bacteria species; 3) determine the cellulolytic bacteria species that has the highest cellulase activity; 4) determine the amylolytic bacteria species that has the highest amylase activity.

\section{MATERIALS AND METHODS}

\section{Materials}

Decayed mangrove stem from Waai sea shore, $0.1 \%$ pepton solution, Nutrient Agar medium, Nutrien broth medium, carboxy methyl cellulose (CMC) plate medium, Amylum Agar (AA), plate medium, $0.1 \%$ congo red solution, $1 \mathrm{M} \mathrm{NaCl}$ solution, $\mathrm{CMC}$ sigma medium, Amylum broth medium.

\section{Methods}

The decayed mangrove stem samples were taken from 10 location point and put into 10 sterile bottle 5 grams each. The samples were collected and took 25 grams, then diluted in $225 \mathrm{ml} 0.1 \%$ pepton water. The suspension were homogenized with shaker in $100 \mathrm{rpm}$ and acclimated during $1 \times 24$ hours. The suspension were diluted at $10^{-1}$ to $10^{-6}$, each diluted sample suspensions were inoculated in $0.1 \mathrm{ml}$ each on Nutrient Agar plate (NA) medium and incubated in $37^{\circ} \mathrm{C}$ during $1 \times 24$ hours.

Each bacteria colony that grow on NA plate medium were isolated and determined their 
cellulose hydrolytic ability in the manner of inoculated on the CMC medium by streak method and incubated in $37^{\circ} \mathrm{C}$ during $1 \times 24$ hours. Furthermore each colony were flooded with $1 \%$ congo red solution for 15 minutes and washes with $1 \mathrm{M} \mathrm{NaCl}$ solution, if there are a clear zone surround the bacteria colony, it indicated that the bacteria have an ability to hydrolyze the cellulose and it means that the bacteria is cellulolytic bacteria.

Each bacteria colony were also determined their amylum hydrolytic ability in the manner of inoculated on the Amylum Agar medium by streak method and incubated in $37^{\circ} \mathrm{C}$ during 1 x 24 hours. Then each colony were flooded with iodine solution, if there are a clear zone surround the bacteria colony, it indicated that the bacteria have an ability to hydrolyze the amylum. It means that the bacteria is amylolytic bacteria. Each cellulolytic and amylolytic bacteria isolates were identify with Microbact ${ }^{\mathrm{TM}}$ System 12B/24E Identification Kits.

Each cellulolytic bacteria species were analysed their cellulase activity in broth CMC Sigma medium. Each amylolytic bacteria species were also analysed their amylase activity in broth amylum medium. The cellulase activity determination use the glucose DNS methods and the amylolytic activity determination were done use the spectrophotometry method.

\section{RESULTS AND DISCUSSION}

Isolation of The Indigenous Bacteria from Decayed Mangrove Stem Waste Product

The isolation result of indigenous bacteria shows that there were 8 bacteria isolates with codes : $b, f, k, m, C, D, K$, and $L$. Each bacteria isolates were determine to know the cellulolytic and amylolytic bacteria isolates.

\section{Determination of The Cellulolytic and Amylolytic Bacteria Species.}

There were 4 cellulolytic bacteria isolates. Each cellulolytic bacteria showed the red colony colors that surround by a clear zone on the CMC medium after flooded with $1 \%$ congo red solution and washed with $1 \mathrm{M} \mathrm{NaCl}$ solution (Figure 1). The determination result were also showed that there were 4 amylolytic bacteria isolates. Each amylolytic bacteria showed a clear zone surround their colonies on the amylum agar medium after flooded with iodine solution (Figure 2). Afterward all bacteria iolates were identified.

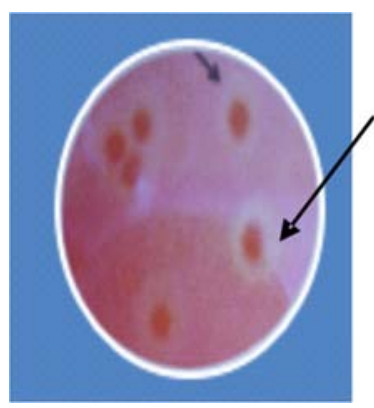

Figure 1

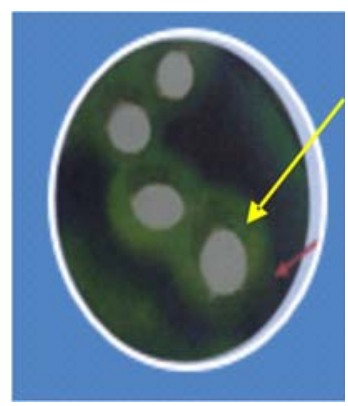

Figure 2

Figure 1. The cellulolytic Bacteria Colonies on CMC medium

The clear zones surround the bacteria colonies ('!) shows that the bacteria have an ability to hydrolyze the cellulose compound in the CMC medium

Figure 2. The Amylolytic Bacteria Colonies on Amylum Agar Medium

The clear zones surround the bacteria colonies ('!) shows that the bacteria have an ability to hyfrolyze the amylum compound in the Amylum Agar medium 
The identification results for each cellulotic and amylolytic bacteria isolates showed in Table 1.

Table 1. The Cellulolytic and Amylolytic Bacteria Species from Decayed Mangrove Stem Waste Product at Waai Seashore, Ambon island.

\begin{tabular}{cclcc}
\hline Number & $\begin{array}{c}\text { Isolate } \\
\text { Code }\end{array}$ & \multicolumn{1}{c}{ Species } & \multicolumn{2}{c}{ Character } \\
\cline { 3 - 5 } & C & Microccocus luteus & + & - \\
2 & D & Bacillus cereus & + & - \\
2 & K & Planococcus citreus & + & - \\
3 & L & Bacillus pumilus & + & - \\
4 & b & Bacillus firmus & - & + \\
5 & f & Nitrobacter sp. & - & + \\
6 & $\mathrm{k}$ & Bacillus mycoides & - & + \\
7 & $\mathrm{~m}$ & Pseudomonas aeruginosa & - & + \\
8 & \multicolumn{7}{l}{} \\
\hline
\end{tabular}

\section{The Cellulase and Amylase Enzyme Activity Analyses Result}

The cellulase activity of each cellulolytic bacteria were analysed to know the bacteria species that have the highest cellulase activity. The amylase activity of each amylolytic bacteria were also analysed to know the bacteria species that have the highest amylase activity. Table 2 shows the cellulase activity of each cellulolytic bacteria species, and Table 3 shows the amylase activity of each amylolytic bacteria species.

Table 2. The Cellulase Activity of Each Sellulolytic Bacteria

\begin{tabular}{|c|c|c|c|c|c|}
\hline \multirow[t]{2}{*}{ Number } & \multirow{2}{*}{$\begin{array}{c}\text { Isolate } \\
\text { Code }\end{array}$} & \multirow[t]{2}{*}{ Species } & \multicolumn{3}{|c|}{ Cellulase Activity (I.U/g) } \\
\hline & & & $\mathrm{X}_{1}$ & $X_{2}$ & $\mathrm{X}$ \\
\hline 1 & C & Micr & 41.576 & 41.425 & 41.501 \\
\hline 2 & D & Bacillus cereus & 47.156 & 47.457 & 47.307 \\
\hline 3 & $\mathrm{~K}$ & Planococcus citreus & 35.997 & 35.846 & 35.922 \\
\hline 4 & L & Bacillus pumilus & 44.743 & 44.291 & 44.517 \\
\hline
\end{tabular}

Table 3. The Amylase Activity of Each Amylolytic Bacteria

\begin{tabular}{cclccc}
\hline Number & $\begin{array}{c}\text { Isolate } \\
\text { Code }\end{array}$ & \multicolumn{1}{c}{ Species } & \multicolumn{3}{c}{ Cellulase Activity (I.U/g) } \\
\cline { 4 - 6 } & & & $\mathbf{X}_{\mathbf{1}}$ & $\mathbf{X}_{\mathbf{2}}$ & $\mathbf{X}$ \\
\hline 1 & $\mathrm{~b}$ & Bacillus firmus & 65.490 & 65.717 & 65.604 \\
2 & $\mathrm{f}$ & Nitrobacter sp. & 79.399 & 80.566 & 79.983 \\
3 & $\mathrm{k}$ & Bacillus mycoides & 56.432 & 53.619 & 55.026 \\
4 & $\mathrm{~m}$ & Pseudomonas aeruginosa & 78.284 & 76.823 & 77.554 \\
\hline
\end{tabular}

Based on the cellulase and amylase activity analyzes result, Bacillus cereus has the highest cellulase activity value and Nitrobactersp. has the highest amylase activity value.

The decayed mangrove stem at the shore would be contribute the environment pollution. However the decayed mangrove stem waste product could be degraded by the soil insects, and then continued by the indigenous bacteria that live in the decayed mangrove stem. The decayed mangrove stem contains compounds, i.e : sellulose, amylum. These compounds is needed by some bacteria species that have an ability to degrade cellulose and amulym. This research result proved that there are 4 indigenous cellulolytic bacteria species, i.e : Micrococcus luteus, Bacillus cereus, Planococcus citreus, and Bacillus 
pumilus. Each bacteria species has a difference cellulase activity value. Bacillus cereus has the highest cellulase activity valae. i.e : $47.307 \mathrm{I} . \mathrm{U} / \mathrm{g}$, so this bacteria species has a haghest potency in cellulose hydrolysis.

The last research result about indigenous cellulolytic bacteria species in sago waste product at Susupu, Nort Moluccas also proved that $B$. cereus is an indigenous cellulolytic bacteria (Hastuti et al., 2012). Commonly the Bacillus genera could be found in the soil and water, including sea water (Hatmanti, 2000). This research were also proved that $B$. cereus is an indigenous bacteria that lived in decayed mangrove stem waste product at Waai seashore, Ambon island. The cellulolytic bacteria could produce a cellulase enzyme. This enzime diffused in the substrat that contains cellulose to degrade the cellulose to celobiose, and then the celobiose were degraded to be glucose-1-phosphate (Chou et al., 2012). Glucose1-phosphate is more soluble than cellulose, so this biodegradation process could help to eliminate the waste product that contains cellulose.

This research result is also proved that there are 4 indigenous amylolytic bacteria species, i.e : Bacillus firmus, Nitrobacter sp., Bacillus mycoides, and Pseudomonas aeruginosa. Bacillus firmus and B. mycoides could be found in the soil and salty soil (Hatmanti, 2000). In this research, these bacteria is also be found as an indigenous bacteria that lived in decayed mangrove stem waste product at seashore soil Waai, Ambon island. Amylolytic bactaria could produce an amylase enzyme that take a role as a biocatalyzator in biodegradation process of amylum to be maltose and then the maltose were degraded to be glucose by maltose enzyme. Glucose is more soluble than amylum, so this biodegradation process could help to eliminate the waste product that contains amylum. Bacillus mycoides could produce a maltose enzyme (Hatmanti, 2000), so this bacteria has an ability to degrade maltose to be glucose. Each amylolytic bacteria species has a difference amylolytic activity value, and Nitrobactersp. has the highest amylase activity value, i.e: $79.983 \mathrm{I.U} / \mathrm{g}$.

The cellulolytic bacteria as well as the amylolytic bacteria species that found in the decyed mangrove stem waste product at Waai seashore, Ambon island could be used in the biodegradation process of cellulose and amylum compounds. These bacteria species is could be also used for degrade another waste product that contains cellulose and amylase. Based on this facts, actually the decayed mangrove stem waste product problem could be solved by use the indigenous cellulolytic and amylolytic bacteria species. So, it is important to take care the seashore environment from pollutants, especially toxic substances, i.e : detergent, oil, etc in order the indigenous bacteria that take a role in the waste product degradation could live optimally.

The conclution are : 1). There are 4 cellulolytic bacteria species, i. e : Micrococcus luteus, Bacillus pumilus, Planococcus citreus, and Bacullus cereus; 2). There are 4 amylolytic bacteria species, i.e : Bacillus firmus, Nitrobacter sp., Bacillus mycoides, and Pseudomonas aeruginosa; 3). Bacillus cereus has the highest cellulase activity; 4). Nitrobactersp. has the highest amylase activity.

\section{REFERENCES}

Apun, K., B.C. Jong, and M.A. Saleh, 2000. Screening and Isolation of a Cellulolytic and Amylolytic Bacillus From Sago Pith Waste. J. Gen. Appl. Microbiol. 46 (1) : 263-267. 
Chou, S.H., Y.Z. Su, Y.W. Lin, M.G. Huang, G.L. Guo, and S. Huang, 2012, Screening, Isolation and Community of Lignocellulose - degrading Bacteria from Herbivores Feces.

Hastuti, U.S., P. Yakub, and H.N. Khasanah, 2012. Isolation and Cellulose Hydrolysis Ability Study of Cellulolytic Bacteria in Sago Waste Product at Susupu, North Moluccas. Proceeding of The $2^{\text {nd }}$ International Conference of Life Sciences. Juli $14-16^{\text {th }}, 2012$. University of Brawijaya Malang. 1 (1) : 61 - 66.

Hastuti, U.S., P. Yakub, and H.N. Khasanah, 2013. Biodiversity of Indigenous Amylolytic and Cellulolytic Bacteria in Sago Waste Product at Susupu, North Moluccas. Proceeding of "The $3^{\text {rd }}$ Basic Science International Conference 2013. April 16 - 17 2013 . University of Brawijaya Malang. Vol. 3 : B 18-1 - 18-4.

Hatmanti, A. 2000. Pengenalan Bacillus spp. Oseana XXV (1) : $31-41$

Lekatompessy. 2010. Analisis Aktivitas Masyarakat yang Berdampak pada Hutan Mangrove di Negeri Waai Kabupaten Maluku Tengah. Skripsi. Tidak diterbitkan. Ambon : Universitas Pattimura - Fakultas Perikanan dan IImu Kelautan.

Meryandini, A., W. Widosari, B. Maranatha, T.C. Sunarti, N. Rachmania, and H. Satria, Isolasi Bakteri Selulolitik dan Karakterisasi Enzimnya, 2009. Makara, Sains 13 (1) April 2009: $33-39$.

Setyawan, A.D., K. Winarno, and P.C. Purnama. 2003. Review: Ekosistem Mangrove di Jawa. Jurnal Biodiversitas. 4 (2) : $130-142$. 